\title{
Changes in the content of milk components during lactation and their influence on lamb rearing of Finnsheep
}

\author{
K. M. CHARON \\ Institute of Biological Bases of Animal Breeding, Warsaw Agricultural \\ University, 05-840 Brwinów, Poland
}

\begin{abstract}
The analysis of milk component content determined by Milkoscan apparatus was carried out on 59 ewes of Finnsheep (a total of 880 records for each component).

Lactations differed in fat $(\mathrm{F})$, protein $(\mathrm{P})$ and lactose $(\mathrm{L})$ content, but the differences were statistically significant $(\mathrm{P} \leqslant 0.01)$ only in some cases (mostly for the 2 nd and 4 th lactations).

The monthly average content of the analysed milk component varied significantly between 1,2 and 3 months of lactation, but as a rule the $\mathrm{F}$ and $\mathrm{L}$ contents were highest at the beginning of lactation and then a decrease was observed, whereas in the case of $\mathrm{P}$ the opposite tendency was observed. The contents of F, P and L for the 2 nd and 4 th lactations within ten-day periods confirmed these tendencies.

The correlations between the milk component content and weight gains of lambs in the suckling period were $0.33,0.28$ and -0.22 , for the content of $\mathrm{F}, \mathrm{P}$ and $\mathrm{L}$, resp. The correlations between the number of lactation and milk composition were respectively for $\mathrm{F}, \mathrm{P}$ and L: $0.25,0.46$ and 0.41 .
\end{abstract}

Index words: Finnsheep, milk components, fat content, protein content, lactose content, weight gain

\section{Introduction}

The chemical composition and nutritive value of sheep milk differs greatly from the milk of the other species of livestock. A great variability of milk yield and milk composition is observed also between breeds within the species as well as big individual differences in milk productivity (7). The milk yield of ewes is very important especially in prolific breeds. It is one of the main factors influencing the growth of lambs. The high correlation between the lamb growth and milk yield of ewes, particularly in the early days of life $-0.9(6)$; 0.75 for singles and 0.81 for twins $(3)-$ confirms this fact.

\section{Materials and methods}

The content of fat $(\mathrm{F})$, protein $(\mathrm{P})$ and lactose (L) in milk of 59 Finnsheep was determined for two years using the Milkoscan ap- 
paratus. The total number of about 880 records for each component was collected.

The variability of milk composition between lactations, months within a lactation (1st, 2nd and 3rd) and ten-day periods of lactation (for the 2 nd and 4th lactation) was analysed.

The correlations between the weight gains of lambs during the suckling period and milk composition were estimated.

\section{Results}

The average milk composition in the tested ewes was: $5.36 \% \mathrm{~F}, 5.39 \% \mathrm{P}$ and $4.75 \%$ L. The lactations differed as to the content of the investigated milk components (Fig. 1). The highest content of milk components was found for the 4th lactation $(5.96 \% \mathrm{~F}, 6.14 \%$ $\mathrm{P}$ and $5.01 \% \mathrm{~L}$ ), and then a decrease was observed in later lactations. The estimated correlations between the number of lactation and milk composition were respectively for $\mathrm{F}, \mathrm{P}$ and L: $0.248 \pm 0.097,0.459 \pm 0.089$ and $0.413 \pm 0.091$.

The content of milk components in the first, second and third months of lactation is shown in figure 2. The F content was highest at the

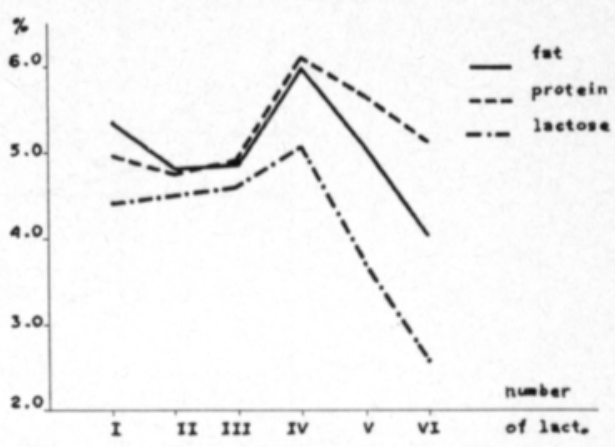

Fig. 1. Contents of main components in milk.

beginning of the 1st and 2nd lactations, then a decrease was observed. In the 3 rd and later lactations the $\mathrm{F}$ content was the highest in the second month. The $\mathrm{P}$ content was the lowest in the first month in all lactations, and then its increase was observed. The opposite tendency was found in the case of L. Its content was highest at the beginning and lowest at the end of lactation. These tendencies were also observed in F, P and L content in milk in tenday periods of the $2 \mathrm{nd}$ and 4 th lactations (Fig. 3).

The number of lambs born per ewe was 2.68 and lambs reared 1.37. The lamb mortality

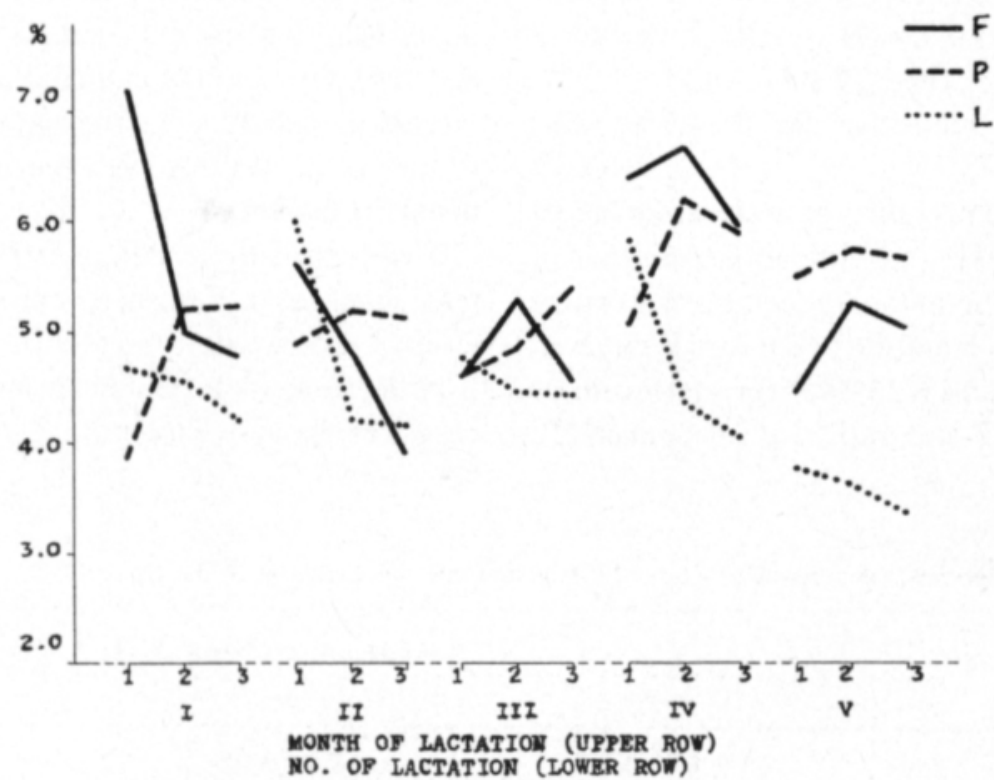

Fig. 2. Milk component contents in various months of lactation. 


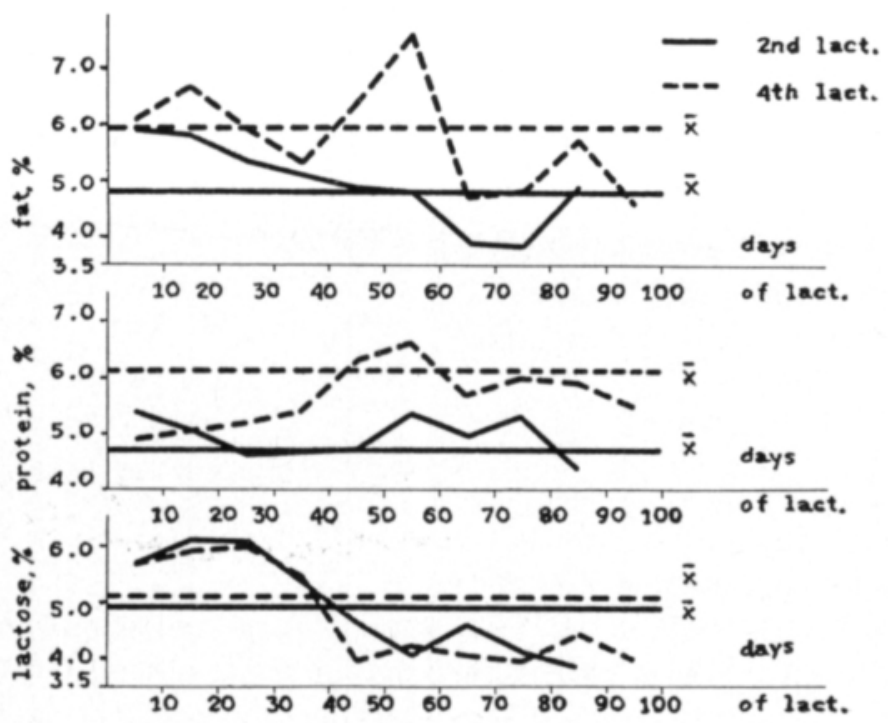

Fig. 3. Milk component contents in 10-day periods of lactation.

was relatively high $(44.9 \%$, stillbirths $4.2 \%)$.

The estimated correlations between the weight gains of lambs and milk composition of their mothers are shown in table 1.

\section{Discussion}

The obtained values of milk composition differ a little from those obtained by SormuNEN and VIRKKUNEN (7) for the same breed. Their estimates for F $(6.3 \%)$ and $\mathrm{L}(5.5 \%)$ were higher, while that for $\mathrm{P}(4.7 \%)$ was lower.

The milk composition of other sheep breeds sometimes differs considerably from that of Finnsheep. The milk of some breeds can be richer: $10.4 \% \mathrm{~F}$ and $10.1 \% \mathrm{P}$ for Dorset ewes (8); $8.8 \% \mathrm{~F}$ and 6.25\% $\mathrm{P}$ for Merinosul de Palas, $8.0 \% \mathrm{~F}$ and $6.01 \% \mathrm{P}$ for Spanca (2), or poorer: $5.1 \% \mathrm{~F}, 4.9 \% \mathrm{P}$ and $4.3 \% \mathrm{~L}$ (5). On the other hand, in the case of some sheep breeds the P content is similar to Finnsheep, whereas the $\mathrm{F}$ content is higher 7.0 as e.g. for Churra (1) $7.2 \%$ for Turcana and $7.5 \%$ for Tsigaia (2). The observed differences in milk composition and milk yield of various sheep breeds result to a certain degree from the way a sheep breed is used.

The obtained correlations between the number of lactation and milk composition suggest that the content of the main milk components increases linearly with the age of the ewe. WoHLt et al. (8) observed the opposite tendency in Dorset.

The decreasing tendency of $\mathrm{P}$ and $\mathrm{L}$ content observed in Finnsheep appeared also in ewes of Corriedale type (4).

A decrease of $\mathrm{F}$ content in milk was also found in the above mentioned sheep breeds,

Table 1. Correlations between weight gains of lambs and milk composition of mothers.

\begin{tabular}{llrr}
\hline $\begin{array}{l}\text { Period } \\
\text { of } \\
\text { rearing }\end{array}$ & \multicolumn{3}{c}{ Correlation coefficient \pm S.E. } \\
\cline { 2 - 4 } 0 & $\mathrm{~F}$ & $\mathrm{P}$ & $\mathrm{L}$ \\
\hline 0 to 28 days & $0.328 \pm 0.167$ & $0.278 \pm 0.180$ & $-0.224 \pm 0.175$ \\
0 to 100 days & $0.040 \pm 0.103$ & $0.116 \pm 0.102$ & $0.100 \pm 0.102$ \\
\hline
\end{tabular}


while the variability of $\mathrm{F}$ content within lactation in Finnsheep depended on the number of lactation.

Milk yield and milk composition of ewes have an important influence on the weight gains of lambs, especially in the first period of their life. In the opinion of SORMUNEN (6) over $75 \%$ of variability of lamb weight gains is connected with the consumption and quality of milk. Thus the correlation between these traits is highest in the first four-six weeks of lamb life, later the values of the correlation are lower. This results undoubtedly from the

\section{References}

1. Alvarez, P.J., Ovejeho, F.J., Guada, J.A. \& GonZALES, J.S., 1980. Prediction of the energy values of ewe's milk. 31st Ann. Meet. EAAP.

2. Gheorghiu, A. \& Oprescu, S., 1982. Qualitative characteristics of ewe milk in some sheep breeds in Romania. Int. Dairy Congr. Moscow.

3. Guzeva, L.A., 1979. Molocnaja produktivnost' ovcematok porody merinofljajś. Mezvedom. Sb. Belorus. Inst. Zivotn. Minsk. vyp. 9: 66-67.

4. Ostonic, M. \& Mı́cınovic, D., 1982. Study of sheep milk quality during lactation. Int. Dairy Congr. Moscow,

5. Sawaya, W.N., Safi, W.J., Al-Shalhat, A.F. \& AlМонамmad, H.M., 1984. Studies on the chemical fact that older lambs consume also other feedstuffs in addition to milk.

\section{Conclusions}

1. The milk of the tested ewes contained: $5.36 \% \mathrm{~F}, 5.39 \% \mathrm{P}$ and $4.75 \% \mathrm{~L}$. The content of milk components increased with the age of the ewe.

2. There was a positive correlation between weight gains of lambs and $\mathrm{F}$ and $\mathrm{P}$ content in milk, while negative correlations were found for $\mathrm{L}$.

composition and nutritive value of sheep milk. Milchwiss. 39 (2): $90-93$.

6. Sormunen, R., 1980. Milk production of Finnsheep ewes. Symp. Intens. Sheep Prod., Helsinki, Aug. 1979: 88-94.

7. Sormunen-Cristian, R. \& VirkKunen, H., 1985. Milk production of Finnsheep ewes, 37th Ann. Meet. EAAP.

8. Wohlt, J.E., Kleyn, D.H., Vandernoot, G.W., SelFRIDGE, D.J., Novotney, C.A., 1981. Effect of stage of lactation, age of ewe, sibling status and sex of lamb on gross and minor constituents of Dorset ewe milk. J. Dairy Sci. 64: 2175-2184. 